\title{
Transformation of Aspergillus oryzae through Plasmid-mediated Complementation of the Methionine-auxotrophic Mutation
}

\author{
Yuzuru Iimura, Katsuya Gomi, Hiroshi Uzu \\ and Shodo HARA \\ National Research Institute of Brewing, 2-6-30, \\ Takinogawa, Kita-ku, Tokyo 114, Japan
}

Received June 27, 1986

\begin{abstract}
A methionine-auxotrophic mutant ( $\mathrm{Met}^{-}$) of Aspergillus oryzae was transformed to prototrophy $\left(\mathrm{Met}^{+}\right.$) with plasmid pKA5-1 carrying a $3.5 \mathrm{Kbp}$ genomic DNA fragment of $A$. oryzae through treatment of spheroplasts with polyethylene glycol 4000 and $\mathrm{CaCl}_{2}$. The highest transformation frequency obtained was 32 transformants per $\mu \mathrm{g}$ DNA. We recovered the transforming plasmid from the $\mathrm{Met}^{+}$transformant cell, showing that this plasmid was derived from the original plasmid, pKA5-1. The mitotic stability of the $\mathrm{Met}^{+}$transformant was about $70 \%$ after growth without selective pressure; the transforming DNA was lost in the $\mathrm{Met}^{-}$clone. These findings suggest that the transforming plasmid, pKA5-1, exists in the transformant cell as a self-replicating circular DNA.

The gene in the $3.5 \mathrm{Kbp}$ DNA fragment, which complements the methionine-auxotrophic mutation, can be used as a selectable marker to construct efficient plasmid vectors for $A$. oryzae.
\end{abstract}

A DNA-mediated transformation system is essentially required for molecular genetics and molecular breeding of Aspergillus. Efficient transformation systems have been developed in Aspergillus nidulans ${ }^{1 \sim 6)}$ and Aspergillus niger. $^{7,8)}$ Therefore, genetic studies have been made possible at the molecular level for these fungi. ${ }^{7,9 \sim 11)}$

Aspergillus oryzae is extensively used for the production of industrial enzymes and for saké making, etc. Therefore, useful strains of $A$. oryzae have been constructed by mutagenesis, ${ }^{12,13)}$ or spheroplast fusion. ${ }^{14)}$ However, because of the lack of vectors carrying selectable genetic markers, studies on DNA recombination have never been performed in the case of $A$. oryzae.

In this paper, we report the successful complementation of the methionine-auxotrophic mutation in $A$. oryzae with a vector DNA containing a genomic DNA fragment of $A$. oryzae and the subsequent recovery of this transforming hybrid vector from $E$. coli. These findings will serve as a basis for the con- struction of efficient transformation systems and plasmid vectors carrying genetic marker for $A$. oryzae.

\section{MATERIALS AND METHODS}

Strains. A strain of E. coli, JA221 (hsd $\mathbf{M}^{+}$hasd $\mathbf{R}^{-}$lac $\mathrm{Y}$ leuB6 $\operatorname{trp} \mathrm{E} 5 \operatorname{rec} \mathrm{A} 1$ ), was used as a gene library for $A$. oryzae and the recovery experiments on the transforming vector from $A$. oryzae. Two mutants of $A$. oryzae, M-28 and $\mathrm{M}-28 \mathrm{~W}$, having the phenotypes of $\mathrm{Met}^{-}$and $\mathrm{Met}^{-}$ white conidia, respectively, were used as recipient strains in the transformation experiments. Mutant M-28 was derived from the wild strain, A. oryzae RIB203, and M28W from mutant M-28. Another wild strain, A. oryzae RIB40, was also used as a DNA donor for a gene library.

Media and growth conditions. Strains M-28, M-28W, RIB203 and RIB40 were grown in DP medium, which was composed of $2.0 \%$ dextrin, $1.0 \%$ polypeptone, $0.5 \%$ $\mathrm{KH}_{2} \mathrm{PO}_{4}, 0.1 \% \mathrm{NaNO}_{3}$ and $0.05 \% \mathrm{MgSO}_{4} \cdot 7 \mathrm{H}_{2} \mathrm{O}$, with vigorous shaking at $30^{\circ} \mathrm{C}$ for $48 \mathrm{hr}$. We also used CzapekDox medium, which was composed of $0.2 \% \mathrm{NaNO}_{3}, 0.1 \%$ $\mathrm{K}_{2} \mathrm{HPO}_{4}, \quad 0.05 \% \quad \mathrm{MgSO}_{4} \cdot 7 \mathrm{H}_{2} \mathrm{O}, 0.05 \% \mathrm{KCl}, 0.001 \%$ $\mathrm{FeSO}_{4}, 3.0 \%$ sucrose and $\mathrm{pH} 5.5$, as a minimal medium. If necessary, $30 \mathrm{mg} /$ liter methionine was added to the Czapek-Dox medium. For conidia formation, the trans- 
formant was incubated on KE medium, which was composed of rice-koji extract ( $\mathrm{ca} .8 \%$ in sugar concentration) containing $2 \%$ agar, at $30^{\circ} \mathrm{C}$ for 5 days.

Plasmids. The plasmid used as a gene library was the yeast-bacterial shuttle vector, YEp13, ${ }^{15)}$ which is composed of bacterial plasmid pBR322, a yeast DNA fragment carrying the $L E U 2$ gene and the yeast $2 \mu \mathrm{m}$ DNA. Plasmid pBR322 was also used in control experiments.

Preparation of mycelial spheroplasts. Mycelia after washing with chilled water were suspended in the cell wall lytic solution, which was composed of $50 \mathrm{~mm}$ phosphate buffer ( $\mathrm{pH} 6.0$ ), $5.0 \% \mathrm{NaCl}$, as an osmotic stabilizer, and $0.5 \mathrm{mg} / \mathrm{ml}$ Oerskovia's enzyme. ${ }^{16)}$ After incubation with gentle shaking at $30^{\circ} \mathrm{C}$ for $2 \mathrm{hr}$, the residual mycelia were removed by filtration on a glass filter. The mycelial spheroplasts in the filtrate were collected by centrifugation.

Preparation of $A$. oryzae whole DNA. The spheroplasts were suspended in NTE buffer, which was composed of $100 \mathrm{~mm} \mathrm{NaCl}, 50 \mathrm{~mm}$ Tris- $\mathrm{HCl}(\mathrm{pH} 8.0)$ and $5 \% \mathrm{SDS}$. The debris was removed by centrifugation at $10,000 \mathrm{rpm}$ for $10 \mathrm{~min}$. The whole DNA in the resultant supernatant was precipitated with ethanol and treated with RNase A.

Construction of a gene library. Plasmid YEp13 was digested with BamHI and then dephosphorylated with bacterial alkaline phosphatase to prevent recircularization, whereas the genomic DNA of $A$. oryzae RIB40 $\left(\mathrm{Met}^{+}\right.$) was partially digested with $\mathrm{Bam} \mathrm{HI}$ or $\mathrm{Sau} 3 \mathrm{~A}$ and then fractionated by sucrose density gradient centrifugation. Then, the DNA fragments of $3 \sim 5 \mathrm{~K}$ bp in length were collected and mixed with the BamHI-digested YEp13. After ligation with T4 DNA ligase, the mixture was used to transform E. coli JA221. About 18,000 colonies of ampicillin-resistant and tetracycline-sensitive transformants were collected as a gene library for $A$. oryzae DNA.

Transformation of A. oryzae. The transformation procedure was based on the method of Hinnen et al. ${ }^{17)}$ with some modifications, as follows. The mycelial spheroplasts were prepared as described above. The resultant spheroplasts $\left(1.0 \times 10^{8}\right.$ cells) were suspended in $100 \mu \mathrm{l}$ of $50 \mathrm{~mm}$ Tris- $\mathrm{HCl}(\mathrm{pH} 7.5)$ containing $5.0 \% \mathrm{NaCl}$ and $10 \mathrm{~mm}$ $\mathrm{CaCl}_{2}$, and then incubated with $1 \sim 10 \mu \mathrm{g}$ of the transforming DNA at room temperature for $5 \mathrm{~min}$. Then, the suspension was added to an equal volume of $70 \%(\mathrm{w} / \mathrm{v})$ polyethylene glycol (PEG) 4000-10 mm Tris- $\mathrm{HCl}$ (pH 7.5)-10 $\mathrm{mm} \mathrm{CaCl} \mathrm{Ca}_{2}$ solution, followed by incubation at room temperature for $10 \mathrm{~min}$. After washing with water twice, the spheroplasts were spread on Czapek-Dox medium containing $5.0 \% \mathrm{NaCl}$ and $2 \%$ agar, and then overlayed with $0.5 \%$ agar containing $5.0 \% \mathrm{NaCl}$. The plate was incubated at $30^{\circ} \mathrm{C}$.
Transformation of E. coli. The conventional method was used. $^{18)}$

Southern blotting and hybridization. The DNA fragments obtained on BamHI-digestion were electrophoretically separated in $1 \%$ agarose gel, and then transferred onto a nitrocellulose filter by Southern's method. ${ }^{19)}$ The probe DNAs were labeled with $\alpha-{ }^{32} \mathrm{P}$-dCTP by means of nick-translation according to Rigby et al. ${ }^{20)}$ DNA immobilized on the nitrocellulose filter was hybridized to ${ }^{32} \mathrm{P}$ labeled probe DNA at $68^{\circ} \mathrm{C}$ according to Maniatis. ${ }^{19)}$

\section{RESULTS}

Transformation of $A$. oryzae with a recombinant plasmid from the gene library

Two methionine-auxotrophic mutants of $A$. oryzae, M-28 and M-28W, were used as recipients in the transformation experiments. The spontaneous reversion frequencies of these mutants to prototrophy $\left(\mathrm{Met}^{+}\right)$were low (below $2 \times 10^{-8}$ ). The mycelia of these mutants were efficiently spheroplastized by Oerskovia's enzyme. ${ }^{16)}$ As compared with the number of the spheroplasts determined by microscopically, the regeneration frequency of the spheroplasts on DP medium containing $5.0 \% \mathrm{NaCl}$ was $80 \sim 86 \%$ for both M-28 and M-28W.

The hybrid plasmids from the gene library were amplified in $E$. coli, and then introduced into spheroplasts of $\mathrm{M}-28$ or $\mathrm{M}-28 \mathrm{~W}$ in the presence of $\mathrm{CaCl}_{2}$ and PEG4000. Out of about 8,000 hybrid plasmids tested, we found that one, designated as pKA5-1, was able to transform both M-28 and M-28W to prototrophy $\left(\mathrm{Met}^{+}\right)$.

\section{Structure of recombinant plasmid pKA5-1}

To characterize the inserted DNA in plasmid pKA5-1, we digested the pKA5-1 DNA with various restriction endonucleases. The inserted DNA fragment $(3: 5 \mathrm{Kbp})$ and linearized YEp 13 DNA $(10.7 \mathrm{~K} \mathrm{bp})$ were observed in the Bam HI-digested pKA5-1 (Fig. 1). Several restriction sites were determined in the $3.5 \mathrm{Kbp}$ inserted fragment (Fig. 2).

\section{Construction of $p K A 5-2$}

In control experiments, we constructed a new hybrid plasmid, designated as pKA5-2, by 


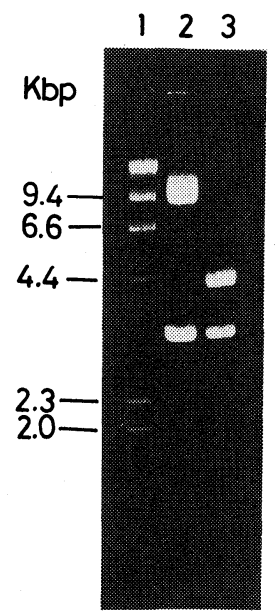

FIG. 1. The Structures of Plasmids pKA5-1 and pKA52.

Agarose gel electrophoresis of BamHI-digested pKA5-1 (2), pKA5-2 (3) and marker DNAs (HindIII-digested $\lambda$ phage) (1). The band corresponding to $3.5 \mathrm{~K} \mathrm{bp}$ is the inserted fragment from the genomic DNA of $A$. oryzae.

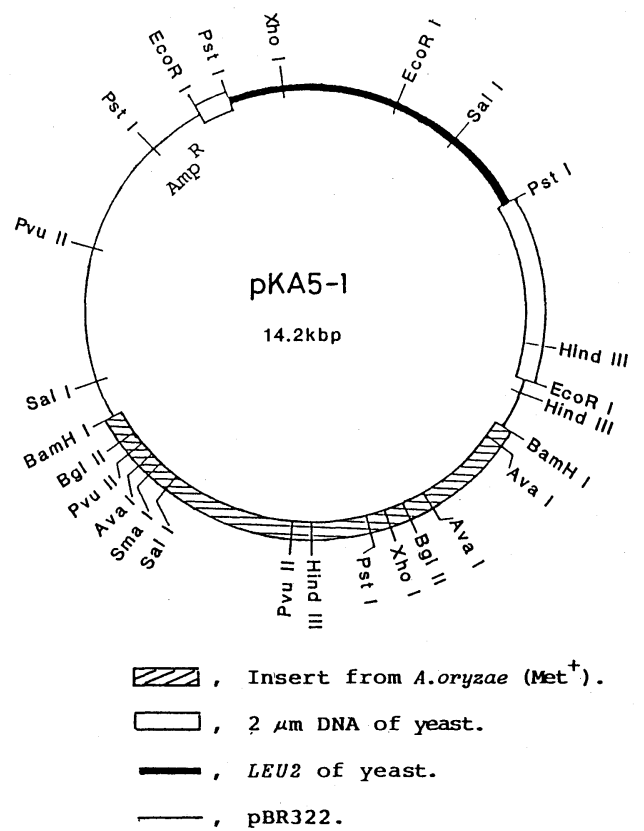

FIG. 2. Restriction Sites of Plasmid pKA5-1.

integrating the $3.5 \mathrm{Kbp}$ fragment into the BamHI-site of pBR322 (Fig. 1).

Transformation frequency with $p K A 5-1$ and pKA5-2

Using plasmid pKA5-1 or pKA5-2 as a
Table I. Transformation of Aspergillus oryzae THROUGH COMPLEMENTATION OF THE MethionineAUXOTROPHIC MUTATION

\begin{tabular}{lcccc}
\hline & & \multicolumn{3}{c}{ Transformation frequency $^{a}$} \\
\cline { 3 - 5 } Recipient & Plasmid & $\begin{array}{c}\text { Large } \\
\text { colony }^{b}\end{array}$ & $\begin{array}{c}\text { Small } \\
\text { colony }^{c}\end{array}$ & Total \\
\hline M-28 & pKA5-1 & 4 & 10 & 14 \\
M-28 & pKA5-2 & 5 & 9 & 14 \\
M-28W & pKA5-1 & 6 & 15 & 21 \\
M-28W & pKA5-2 & 5 & 27 & 32 \\
\hline
\end{tabular}

a Number of colonies obtained on transformation with $1 \mu \mathrm{g}$ of transforming DNA.

$b$ Colonies showing vigorous growth.

c Abortive colonies.

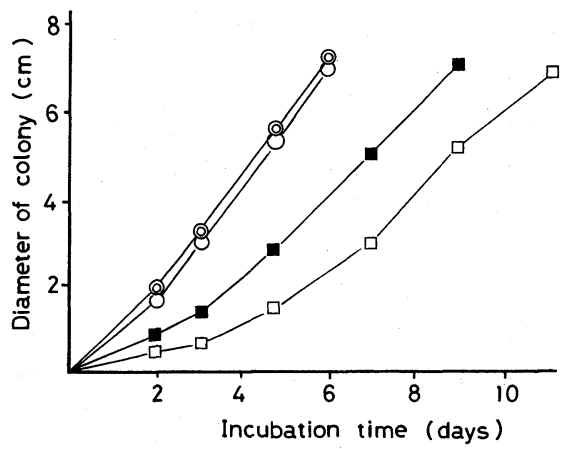

Fig. 3. Growth Rates of the $\mathrm{Met}^{+}$Transformants and the Recipients.

The transformant and recipient cells were grown on the minimal medium and the minimal medium supplemented with $30 \mathrm{mg} /$ liter methionine, respectively. The growth is expressed as the diameter of colonies. $\square$, transformant M28 (pKA5-1); $\square$, transformant M-28W (pKA5-1); O, recipient $\mathrm{M}-28$; (), recipient $\mathrm{M}-28 \mathrm{~W}$.

transforming vector, we examined the transformation frequency of the recipients, M-28 and $\mathrm{M}-28 \mathrm{~W}$ (Table I). The frequency was $14 \sim 32$ colonies per $\mu \mathrm{g}$ DNA, while no transformant was obtained in the experiments using YEp13 or pBR322. These results show that the $\mathrm{Met}^{+}$phenotype of these transformants was due to plasmid-mediated complementation of the $\mathrm{Met}^{-}$mutation, depending on the $3.5 \mathrm{Kbp}$ inserted DNA, and not on the yeast DNAs in YEp13, or on pBR322.

The frequency in these experiments was similar to that observed for the trans- 
formation of Aspergillus, ${ }^{1}{ }^{3)}$ but much less than that reported in other transformation studies. ${ }^{4 \sim 6,11)}$

Two types of transformant colonies were observed on growth on the minimal medium. One showed abundant growth and subsequent sporulation; the other showed poor growth, and was abortive. A similar phenomenon was reported for the transformation of $A$. nidulans by Tilburn et al. ${ }^{2)}$

\section{Growth rates of transformants}

We isolated two transformants with pKA51, which showed vigorous growth on the minimal medium, and estimated their growth rates (Fig. 3). The growth rates of the transformants were lower than those of the auxotrophic recipients $\left(\mathrm{Met}^{-}\right)$grown on the minimal medium supplemented with methionine, although these transformant cells were morphologically similar to the recipient cells.

\section{Stability of transformants}

To determine the mitotic stability of the $\mathrm{Met}^{+}$transformants, the cells were incubated on $\mathrm{KE}$ medium, which contained methionine, at $30^{\circ} \mathrm{C}$ for 10 days, and then the resultant conidia were transferred onto the minimal medium to assay the reversion frequency to $\mathrm{Met}^{-}$. As shown in Table II, the reversion frequency was high, showing that all the $\mathrm{Met}^{+}$ transformants were unstable.

Table II. Mitotic Stability of The $\mathrm{Met}^{+}$Phenotype IN THE TRANSFORMants

\begin{tabular}{|c|c|c|c|}
\hline Transformant $^{a}$ & $\begin{array}{l}\text { Number of } \\
\text { colonies } \\
\text { tested }^{b}\end{array}$ & $\begin{array}{l}\text { Number of } \\
\text { colonies } \\
\left(\mathrm{Met}^{+}\right)^{c}\end{array}$ & $\begin{array}{l}\text { Reversion } \\
\text { rate }^{d} \\
(\%)\end{array}$ \\
\hline M-28 (pKA5-1) & 108 & 69 & 36 \\
\hline M-28 (pKA5-2) & 103 & 76 & 26 \\
\hline M-28W (pKA5-1) & 116 & 81 & 30 \\
\hline M-28W (pKA5-2) & 118 & 86 & 27 \\
\hline $\begin{array}{l}\text { a Transformation } \\
\text { parentheses. }\end{array}$ & $\mathrm{n}$ was due & to the 1 & plasmid in \\
\hline \multirow{2}{*}{\multicolumn{4}{|c|}{$\begin{array}{l}\text { b Colonies which formed conidia on KE medium. } \\
c \text { Colonies grown on minimal medium after incu- } \\
\text { bation without selective pressure. }\end{array}$}} \\
\hline & & & \\
\hline \multicolumn{4}{|c|}{ d Rate of reversion to $\mathrm{Met}^{-} ; b-c / b \times 100$} \\
\hline
\end{tabular}

Fate of the transforming plasmid in transformant cells

To confirm that the $\mathrm{Met}^{+}$transformation of A. oryzae was due to plasmid-mediated complementation of the $\mathrm{Met}^{-}$mutation, we investigated as to whether or not the transforming plasmid was present in the whole DNA prepared from $\mathrm{Met}^{+}$transformant cells of $\mathrm{M}$ $28 \mathrm{~W}$, which were grown in DP medium, by means of Southern blotting analysis using labeled pKA5-1 as a probe. Consequently, for the BamHI-digested whole DNA of the transformant, two distinct bands were observed, which corresponded to the $3.5 \mathrm{Kbp}$ inserted DNA and linearized YEp13 DNA, respectively, while for the BamHI-digested whole DNA of M-28W ( $\mathrm{Met}^{-}$), only one band corresponding to the $3.5 \mathrm{Kbp}$ DNA was observed (Fig. 4-I). In control experiments using labeled YEp13 as a probe, only one band corresponding to the linearized YEp13 was observed for

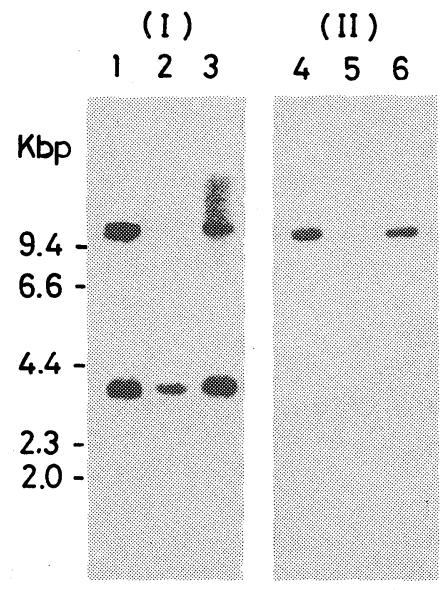

FIG. 4. Southern Blotting Analysis of Whole DNA of $A$. oryzae.

Whole DNAs were prepared from the M-28W transformant obtained with pKA5-1 and the recipient cells. Ten micrograms of whole DNA was loaded in each lane. ${ }^{32} \mathrm{P}$-Labeled probe DNA (ca. $17 \mu \mathrm{Ci} / \mu \mathrm{g}$. DNA) was hybridized at $68^{\circ} \mathrm{C}$ for $16 \mathrm{hr}$; filters were washed at $42^{\circ} \mathrm{C}$ in $0.1 \times \mathrm{SSC}$ for $60 \mathrm{~min}$. (I) and (II) show hybridization using ${ }^{32} \mathrm{P}-\mathrm{pKA} 5-1$ and ${ }^{32} \mathrm{P}-\mathrm{YEp} 13$, respectively. (1) and (4) BamHI-digested pKA5-1 (control); (2) and (5) BamHI-digested whole DNA of the recipient cells; (3) and (6) BamHI-digested whole DNA of the transformant cells. 
the BamHI-digested whole DNA of the transformant, while no band was seen for that of M-28W ( Met $^{-}$) (Fig. 4-II).

\section{Recovery of the plasmid from the transformant}

To examine the possibility that pKA5-1 might exist as a self-replicating plasmid in the $\mathrm{Met}^{+}$transformant cells, we attempted to transfer the plasmid from $\mathrm{Met}^{+}$ransformant cells of either M-28 or M-28W, which were grown in DP medium at $30^{\circ} \mathrm{C}$ for $48 \mathrm{hr}$, to $E$. coli. The transformation frequency in these experiments was low (10-16 colonies per $\mu \mathrm{g})$. One colony, designated as ECK-5, was isolated from the ampicillin-resistant and tetracycline-sensitive $E$. coli transformants. On the other hand, no transformant was obtained on transformation of $E$. coli using the whole DNA of the $\mathrm{Met}^{-}$revertant, which was generated on incubation without selective pressure.

\section{Hybridization analysis of the plasmid recovered in E. coli}

To prove that $E$. coli transformant ECK-5 contained the original plasmid, pKA5-1, we carried out Southern blotting analysis for the whole DNA of ECK-5 (Fig. 5). On the hy-

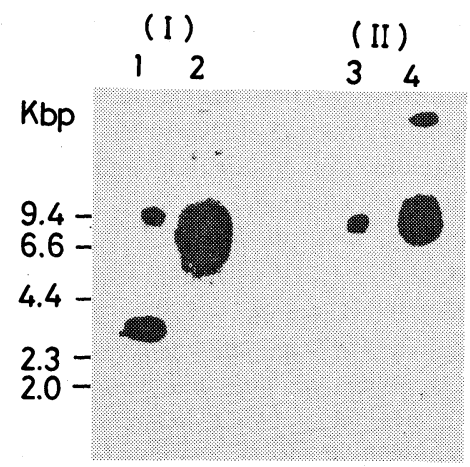

FIG. 5. Southern Blotting Analysis of the BamHIdigested Whole DNA of the E. coli Transformant.

Whole DNA was prepared from the $E$. coli transformant cells obtained by introducing the whole DNA of the Met ${ }^{+}$ transformant of $A$. oryzae. ${ }^{32} \mathrm{P}$-Labeled probe DNA was hybridized at $68^{\circ} \mathrm{C}$; filters were washed at $50^{\circ} \mathrm{C}$ in $0.1 \times \mathrm{SSC}$ for $60 \mathrm{~min}$. (I) and (II) show hybridization using ${ }^{32} \mathrm{P}-\mathrm{pK}$ A5-1 and ${ }^{32} \mathrm{P}-\mathrm{YEp} 13$, respectively. (1) and (3) BamHI-digested whole DNA; (2) and (4) BamHI-digested YEp13, as a control. bridization of the BamHI-digested whole DNA to labeled pKA5-1, two distinct bands were observed, which corresponded to the $3.5 \mathrm{Kbp}$ inserted DNA of pKA5-1 and linearized YEp13 DNA, respectively. Besides, on hybridization to labeled YEp13, only one band corresponding to the linearized YEp13 was detected. These results show that the transforming DNA in ECK-5 is derived from the original plasmid, pKA5-1.

\section{DISCUSSION}

In the gene cloning of Aspergillus, the complementation of a mutant allele in a heterologous organism has been used for the identification of an isolated gene. ${ }^{9,21)}$ Besides, since this method is limited to genes which can be expressed in a heterologous organism, the direct cloning of genes has been achieved through the complementation of a mutation with plasmid DNA carrying a fragment from the genomic DNA of a wild type strain for $A$. nidulans, ${ }^{2 \sim 4,6,11)}$ but not for $A$. oryzae.

In this study, we attemped the direct cloning of the gene which complements the methionine-auxotrophic mutation of $A$. oryzae and isolated a hybrid plasmid from the gene library for A. oryzae, which was able to change the phenotype from $\mathrm{Met}^{-}$to $\mathrm{Met}^{+}$, being the first instance of transformation in A. oryzae. The $\mathrm{Met}^{+}$phenotype of this transformant was probably due to the complementation of the mutant allele with the gene carried by the 3.5 Kbp inserted DNA fragment of pKA5-1.

Generally, transforming DNA within a transformant cell is integrated into a homologous region of the chromosome, or present as a self-replicating circular plasmid. In this study, the occurrence of abortive transformants (Table I) and the instability of the transformant on growth without selective pressure (Table II), or loss of the transforming plasmid during mitotic division, suggest that this hybrid plasmid exists as a self-replicating DNA in the transformant. Besides, the plasmid recovered from the $\mathrm{Met}^{+}$transformant was proved by Southern blotting analysis to be 
derived from the original plasmid (Figs. 4 and $5)$. The frequency and the stability of the transformation with hybrid plasmid pKA5-2, which was composed of the $3.5 \mathrm{Kbp}$ inserted DNA and pBR322, were similar to those in the case of pKA5-1 (Table I). These results show that the self-replication of these hybrid plasmids was due to the $3.5 \mathrm{Kbp}$ inserted DNA in pBR322, and not to the yeast DNA in YEp13. However, we cannot conclude that the transformation depends only on the self-replicating plasmid, because there is a possibility that the occurrence of free circular plasmid is due to excision of the integrated plasmid on recombination, as reported for the transformation of A. nidulans by Johnstone. ${ }^{22)}$ In this study, the fate of the transforming DNA was not clarified. Further studies are necessary.

In the recovery test of the transforming plasmid from the $\mathrm{Met}^{+}$transformant, the transformation frequency of $E$. coli was found to be low. This shows that the copy-number of the transforming DNA in the transformant cell is small. The delay in the growth of the transformant (Fig. 3) also suggests that the copy-number of the gene complementing the $\mathrm{Met}^{-}$mutation is small.

A vector with a high-transformation frequency and a high copy-number is desired for practical use in $A$. oryzae transformation. To construct such an effective vector, the gene which is involved in the complementation of the $\mathrm{Met}^{-}$mutation can be used as a marker.

Acknowledgments. We wish to thank Mr. M. Takahashi and Mr. H. Kadowaki for their helpful technical assistance, and Dr. T. Nishiya for his helpful advice.

\section{REFERENCES}

1) D. J. Ballance, F. P. Buxton and G. Turner, Biochem. Biophys. Res. Commun., 112, 284 (1983).

2) J. Tilburn, C. Scazzocchio, G. G. Taylor, J. H.
Zabicky-Zissman, R. A. Lockington and R. W. Davies, Gene, 26, 205 (1983).

3) M. M. Yelton, J. E. Hamer and W. E. Timberlake, Proc. Natl. Acad. Sci. U.S.A., 81, 1470 (1984).

4) M. A. John and J. F. Peberdy, Enzyme Microb. Technol., 6, 386 (1984).

5) D. J. Ballance and G. Turner, Gene, 36, 321 (1985).

6) K. Wernars, T. Goosen, L. M. J. Wennekes, J. Visser, C. J. Bos, H. W. J. van den Broek, R. F. M. van Gorcom, C. A. M. J. J. van den Hondel and P. H. Pouwels, Curr. Genet., 9, 361 (1985).

7) J. M. Kelly and M. J. Hynes, EMBO J., 4, 475 (1985).

8) F. P. Buxton, D. I. Gwynne and R. W. Davies, Gene, 37, 207 (1985).

9) M. M. Yelton, J. E. Hamer, E. R. de Souza, E. J. Mullaney and W. E. Timberlake, Proc. Natl. Acad. Sci. U.S.A., 80, 7576 (1983).

10) B. L. Miller, K. Y. Miller and W. E. Timberlake, Mol. Cell Biol., 5, 1714 (1985).

11) IL. Johnstone, S. G. Hughes and A. J. Clutterbuck, EMBO J., 4, 1307 (1985).

12) S. Hara, S. Sugama, K. Hongo, T. Oba, Y. Hasegawa and H. Murakami, J. Ferment. Technol., 52, 306 (1974).

13) S. Hara, S. Sugama, K. Noshiro and H. Murakami, J. Soc. Brew. Jpn., 70, 348 (1975).

14) K. Gomi, H. Inoue and T. Tanaka, Abstracts of Papers, Annual Meeting of Agric. Chem. Soc. Japan, 1984, p. 83.

15) J. R. Broach, J. N. Strathern and J. B. Hicks, Gene, 8, 121 (1979).

16) K. Gomi, D. Hosaka and H. Momose, Abstracts of Papers, Annual Meeting of Agric. Chem. Soc. Japan, 1985 , p. 448.

17) A. Hinnen, J. B. Hicks and G. R. Fink, Proc. Natl. Acad. Sci. U.S.A., 75, 1929 (1978).

18) T. Maniatis, E. F. Fritsch and J. Sambrook, "Molecular Cloning," Cold Spring Harbor Laboratory, 1982, pp. $249 \sim 253$.

19) T. Maniatis, E. F. Fritsch and J. Sambrook, "Molecular Cloning," Cold Spring Harbor Laboratory, 1982, pp. $382 \sim 389$.

20) P. W. J. Rigby, M. Dieckmann, C. Rhodes and P. Berg, J. Mol. Biol., 113, 237 (1977).

21) M. E. Penttilä, K. M. H. Nevalainen, A. Raynal and J. K. C. Knowles, Mol. Gen. Genet., 194, 494 (1984).

22) IL. Johnstone, Microbiol. Sci., 2, 307 (1985). 